\title{
Use of Anionic Polysaccharides in the Development of 3D Bioprinting Technology
}

\author{
Chia Tai ${ }^{1}$, Soukaina Bouissil ${ }^{2}$, Enkhtuul Gantumur ${ }^{1}$, Mary Stephanie Carranza ${ }^{1}$, Ayano Yoshii ${ }^{1}$, \\ Shinji Sakai ${ }^{1}$, Guillaume Pierre ${ }^{2}$, Philippe Michaud ${ }^{2} \mathbb{D}$ and Cédric Delattre ${ }^{2, *(1)}$ \\ 1 Division of Chemical Engineering, Department of Materials Engineering Science, \\ Graduate School of Engineering Science, Osaka University 1-3 Machikaneyama-cho, Toyonaka, \\ Osaka 560-8531, Japan \\ 2 Université Clermont Auvergne, CNRS, SIGMA Clermont, Institut Pascal, F-63000 Clermont-Ferrand, France \\ * Correspondence: cedric.delattre@uca.fr
}

Received: 26 May 2019; Accepted: 25 June 2019; Published: 27 June 2019

\begin{abstract}
Three-dimensional (3D) bioprinting technology is now one of the best ways to generate new biomaterial for potential biomedical applications. Significant progress in this field since two decades ago has pointed the way toward use of natural biopolymers such as polysaccharides. Generally, these biopolymers such as alginate possess specific reactive groups such as carboxylate able to be chemically or enzymatically functionalized to generate very interesting hydrogel structures with biomedical applications in cell generation. This present review gives an overview of the main natural anionic polysaccharides and focuses on the description of the 3D bioprinting concept with the recent development of bioprinting processes using alginate as polysaccharide.
\end{abstract}

Keywords: 3D bioprinting; alginate; polysaccharide; biomedical; glucuronan

\section{Introduction}

At the opening scene of the famous French film entitled the "Fifth Element", released in cinemas in 1997 with Bruce Willis as main actor, the body of the beautiful Milla Jovovich was built by a three-dimensional (3D) printer using her genetic code extracted from a fragment of her skeletal tissue Of course, this technology was considered, and will always be, fictional but it is potentially becoming reality with the rapid development of 3D bioprinting using natural biopolymers such as polysaccharides.

3D printing involves various processes in which material is joined or solidified under computer control to create a three-dimensional object from digital models. 3D printing is not a new method as the two primitive 3D printing or additive manufacturing methods were invented in 1981 by Hideo Kodama of the Nagoya Municipal Industrial Research Institute to make layer-by-layer three-dimensional plastic materials using a photosensitive polymer called Tevistar and manufactured by Teijin [1]. Hideo Kodama was also among the first to develop a single-beam laser curing approach. 3D printing technologies have recently become accessible due to the expiration of key patents such as that of the fused deposition modeling printing process which expired in 2009 [2] leading to a drop of 3D printers' prices. The term 3D printing referred to the polymer technologies where additive manufacturing was used in metalworking. The main 3D printing categories described in literature are stereolithography (SLA), fused deposition modeling (FDM) and selective laser sintering (SLS) [3]. A fourth technique usually grouped with SLA is digital light processing (DLP). SLA (the oldest additive manufacturing technique) uses a high-powered laser to harden a liquid resin leading to the desired 3D shape. FDM is based on the deposition of a continuous thermoplastic filament by a print head moved under the control of a computer. SLS is a technique using a laser power source to sinter a powder of polymer. 
3D printing is one the most promising technologies in regenerative medicine for in situ creation of 3D tissues or organs after using direct copies of the patient's organ parameters obtained with 3D imaging techniques such as tomography, for example [4]. The 3D-printed structures colonized by tissue-selected cells under the action of specific growth factors can be also used to build in vitro models for the testing of bioactive compounds in pharmaceutic and cosmetic fields [5]. The 3D printing resulting in cell-laden constructs is call as '3D bioprinting', and the ink suspending cells is called 'bioink'. The process in 3D bioprinting and the components of the bioink are required not to damage the cells. In addition, the components of bioink must be biocompatible for avoiding adverse responses after implantation in vivo. Regarding the application of natural polysaccharides, 3D bioprinting technologies mainly involve inkjet-based printing, extrusion-based printing, light-assisted 3D printing and particle fused-based 3D printing [3]. Polysaccharides are highly complex biopolymers composed of monosaccharides (mainly hexoses and pentoses) with linear or ramified structures. They have various degrees of solubility in water depending on: the monosaccharide's composition, the nature of the glycosidic bonds that link the monosaccharides to each other, and the possible presence of non-sugars constituents. This variety of condensation linkages and the variations in monomer sequences generates a plethora of possible architecture and shapes [6]. Polysaccharides are abundant in nature as they have been described in microorganisms (including bacteria, cyanobacteria, microalgae and fungi), mushrooms, terrestrial plants, macroalgae and animals [6-9]. In view of their numerous hydroxyl groups, polysaccharides can be modified with desired chemical moieties to obtain 3D-crosslinked structures with tunable mechanical properties [10]. Generally, in the last decades, the most described polysaccharides used in bioink to obtain 3D bioprintable scaffolds and hydrogels are hyaluronic, acid, alginate, chondroitin sulfate, chitosan, agarose, gellan, pullulan or cellulose [11,12]. Their main advantages are their appropriate mechanical/rheological properties, printability, biocompatibility, biodegradability and non-toxicity. Among them, polyuronides and, above all, alginates-which are linear anionic polysaccharides that have been shown to be capable of self-assembly to form acidic or ionic crosslinked hydrogels with interesting mechanical properties-are considered ideal candidates with or without chemical functionalization [13-15]. Anionic polysaccharides such as alginate are composed of carboxylated sugars (COO-) which are specific reactive groups largely described in literature to be easily functionalized by a chemical or enzymatic process in order to generate interesting hydrogel structures with biomedical applications in tissue engineering. Consequently, this review aims to discuss state of the art 3D printing technologies and its application to design biomaterials using polysaccharides and predominantly, anionic polysaccharides such as alginates and hyaluronic acid.

\section{Overview of Natural Anionic Polysaccharides from Plant, Bacteria and Algae}

Carbohydrate polymers from natural sources have been studied and utilized in the pharmaceutical and biotechnological industries for many years. Besides its desired gelling properties, these natural polysaccharides have been used as hydrogels for 3D bioprinting [3-5,10,11]. For example, in the presence of divalent cations, such as calcium, anionic polysaccharides are able to form gels because of associations between the calcium ion and the acid residues. This section gives a short emphasis on the most described and principal natural anionic polysaccharides of interest, including: polygalacturonic acid (PGA), polyglucuronic acid (PGU) and alginate reported for their gelling properties and their potential for 3D bioprinting technology.

\subsection{Polygalacturonic Acid from Pectin}

Pectin is a glucidic polymer of high molecular weight, present practically in all plants where it contributes to the cell structure [16,17]. The term pectin covers a number of polymers, which vary according to their molecular weight, chemical configuration and neutral sugars content [17]. It is an heteropolysaccharide found in and between plant cell walls. The amount and composition of the polymer vary with the plant species but all pectins are based on a backbone of anhydrogalacturonic acid [17,18]. The dominant feature of pectins consists of a linear chain of $\alpha$-(1,4)-linked D-galacturonic 
acid (GalA) units called polygalacturonic acid (PGA) (Figure 1) $[17,19,20]$, together with various neutral sugars, mainly rhamnose (Rha), arabinose (Ara) and galactose (Gal). In addition, non-sugar components such as methanol, acetic acid and ferulic acid (FerA) are often associated with pectic polysaccharides (Table 1). The galacturonic acid chain is partly esterified as methyl esters. Although the esters are the most significant components on the galacturonic acid backbone, other chemicals, such as acetyl, can be important in specific pectin types [17]. The percentage of galacturonic acid in the whole molecule is defined as the galacturonic acid content (\% GA), which is set at a minimum of $65 \%$ in the definition of pectin as a food additive. The percentage of esterified galacturonic acid units relative to the total number of galacturonic acid units in the pectin structure is defined, respectively, by the degree of methylation (DM) and the degree of acetylation (DA) $[17,18]$.

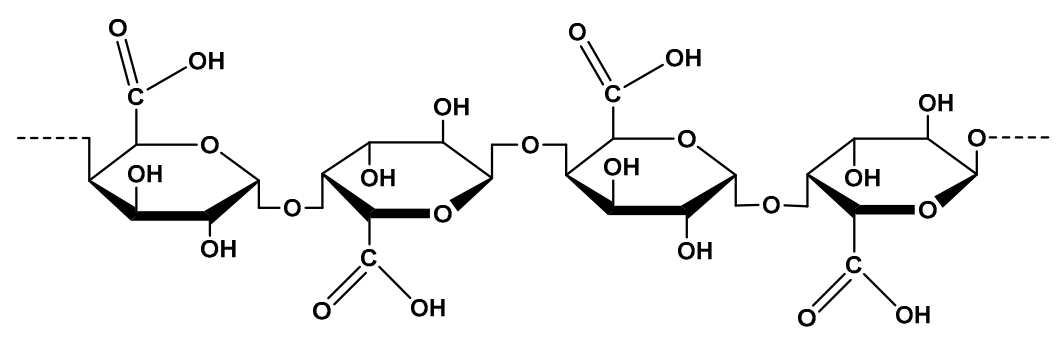

Figure 1. Structure of $\alpha-(1,4)$-D-polygalacturonic acid (PGA).

Table 1. Galacturonic acid and neutral sugars contents $(\mathrm{mg} / \mathrm{g})$ of some acid extracted pectins.

\begin{tabular}{cccccccc}
\hline Origin & GalA & Rha & Ara & Xyl & Gal & FerA & Reference \\
\hline Citrus & 792 & 14 & 11 & 2 & 24 & ND $^{*}$ & {$[21]$} \\
\hline Apple & 731 & 23 & 44 & 17 & 42 & ND & {$[21]$} \\
\hline Quinoa & 625 & 38 & 33 & 18 & 51 & 3 & {$[22]$} \\
\hline Carrot & 613 & 43 & 35 & 3 & 79 & ND & {$[23]$} \\
\hline Beet & 558 & 28 & 124 & 3 & 47 & 7 & {$[24]$} \\
\hline Grape & 533 & 58 & 77 & 6 & 44 & ND & {$[25]$} \\
\hline Pea & 449 & 102 & 144 & 155 & 75 & ND & {$[26]$} \\
\hline Pear & 380 & ND & ND & ND & ND & ND & {$[20]$} \\
\hline Potato & 350 & ND & ND & ND & ND & ND & {$[20]$} \\
\hline Glasswort & 289 & 22 & 462 & 3 & 43 & 17 & {$[27]$} \\
\hline & & & $*$ ND: not determined. & & &
\end{tabular}

Colorimetric procedures are the most widely used methods for galacturonic acid content determination. In concentrated acid medium, furfuric derivatives are generated and conjugated with aromatic compounds (m-hydroxybiphenyl, 3,5-dimethylphenol) [28,29] to give colored products that are quantified by colorimetry. Thibault (1979) [30] automated the m-hydroxybiphenyl method. Titrimetry is also widely used and is the main reference method for commercial pectin quantification. In their acidic form, pectins are titrated by a dilute alkali, saponified and titrated again. This "double titration" gives access to both DM (degree of methylation) and galacturonic acid content, but it suffers from a lack of specificity and cannot be used on acetylated pectins. The method also requires large quantities of pectins (from $100 \mathrm{mg}$ to $1 \mathrm{~g}$ ) for its operations. Regarding rheological behavior, solutions with more than $1 \%(\mathrm{w} / \mathrm{v})$ pectin exhibit pseudoplastic behavior and are strongly affected by calcium. They gel in the presence of calcium ions or other divalent cations. Then, there are "eggbox" junction zones between the regular regions of acidic homogalacturonans, which can stack on top of one another. It is clear that the dominant factor in the gelling of pectin strongly depends on its degree of esterification, but the structure of the complex network is most often the result of a combination of several mechanisms. The assertion that high ester pectins will gel with sugars and acids, while gelling 
with low ester and calcium pectins, is certainly valid, but that calcium can certainly alter the gelling of high-ester pectins, as well as $\mathrm{pH}$ and soluble solids affect the low gelling ester content of pectin $[17,18]$. The rigidity of the gel depends on several factors: the proportion of homogalacturonan (HGA) zones and branches, the degree of esterification, the $\mathrm{pH}$ which must allow the ionization of the acid functions, and the calcium ion content of the medium. These interesting gelation effect of polygalacturonic acid (PGA) in presence of calcium could be a very interesting properties in 3D bioprinting technology development since these similar gelling properties were successfully investigate with another anionic polysaccharides such as alginate for tissue engineering technology.

\subsection{Polyglucuronic Acid from Bacteria, Fungi and Green Algae}

Polyglucuronic acids are homopolymers of glucuronic acid partially acetylated and initially isolated from microorganisms, such as the bacterial strain Sinorhizobium meliloti M5N1CS, which produces an extracellular polysaccharide with interesting viscosimetric and gelling properties consisting only of glucuronic acids. Gas chromatography and ${ }^{1} \mathrm{H}$ nuclear magnetic resonance (NMR) analysis revealed the presence of a single peak that corresponds to $\beta$-(1,4)-linked glucuronic acid (Figure 2) $[14,31,32]$.

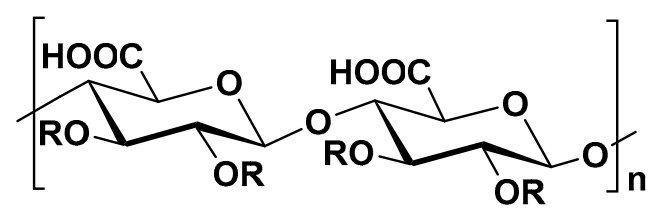

Figure 2. Structure of $\beta$-(1,4)-D-polyglucuronic acid (PGU) from Sinorhizobium meliloti M5N1CS. With $\mathrm{R}=\mathrm{H}$ or $\mathrm{COCH}_{3}$ (acetyl group).

Gelling properties have also been reported in the presence of monovalent, divalent or trivalent cations as a function of polymer concentration and ionic strength [14,32]. Glucuronan can form thermo-reversible gels in the presence of monovalent cations in the form of $\mathrm{Na}^{+}$high ionic. Thermally stable gels were obtained with divalent cations $\left(\mathrm{Ca}^{2+}, \mathrm{Cu}^{2+}\right.$, and $\left.\mathrm{Ba}^{2+}\right)$ and the resistance of the gels was modulated by the degree of acetylation of the polymer that disrupts the ionic interaction [14]. The production of glucuronan by the S. meliloti strain M5N1CS and its use in food products, agriculture, pharmacy, cosmetics or water purification, especially in the form of a gelling agent, thickener, moisturizer, stabilizer, have been claimed in the first patent describing the use of $\beta$-(1,4)-D-polyand oligoglucuronic acids in chelatant or flocculant applications but also in various fields of applications [14,33,34].

Another bacterial strain producing cellulose was isolated from rotten apples. It has been identified as Gluconacetobacter hansenii based on its physiological characteristics and the sequence of the gene coding for $16 \mathrm{~S}$ rDNA. Specifically named G. hansenii PJK [35,36], it was used to produce water-soluble polysaccharides composed of glucuronic acid [35-38]. High-performance liquid chromatography (HPLC) analysis of the polysaccharide hydrolysates produced by this strain revealed the presence of glucuronic acid $[39,40]$. Further analysis by NMR determined the structure of this polymer that can be composed of $\alpha$-glucuronic acid rather than $\beta$-glucuronic acid $[39,40]$. Part of the polysaccharide mixture was composed of unsaturated $\alpha-(1,4)$-oligoglucuronic acids [39,40]. These oligosaccharides have good emulsifying properties and sufficient thermal stability to be commercially developed [39]. Their production from a chemically defined medium was expensive, but the strain produced large amounts $(112.65 \mathrm{~g} / \mathrm{L})$ of these oligomers on fermentation broth waste from beer $[39,41]$.

In fungal species of the genus Mucor, the fibrillar structure of the wall is composed of chitin and chitosan [42], which have been incorporated in matrix materials mainly composed of polymers, containing large amounts of glucuronic acid [43]. Two polymers of different acidity were extracted from the mycelial walls of Mucor rouxii. The first was an heteropolymer composed of D-glucuronic acid, D-mannose, D-galactose and L-fucose. It was designed as mucoran. The other polymer contained large amounts of D-glucuronic acid and was designed as mucoric or fungal $\beta$-(1,4) glucuronan acid [44]. 
Previous studies have also revealed the presence of $\beta$-(1,4)-D-polyglucuronic acid in the cell walls of several green algae $[45,46]$.

Regarding the very good gelling properties of PGU using divalent ions which gave thermally stable gels [14,33], it is important to mention that PGU could be efficiently use as the basal hydrogel of bioinks and investigated for new application in 3D bioprinting dedicated to tissue engineering as already done with alginate.

\subsection{Alginate from Brown Algae and Bacteria}

\subsubsection{Alginate from Brown Algae}

Alginates are quite abundant in nature since they occur both as a structural component in marine brown algae (Phaeophyceas), comprising up to $40 \%$ of the dray algae such as Laminaria digitata, $L$. hyperborea and Macrocystis pyrifera. Alginates are unbranched binary copolymers, consist of (1->4) linked $\beta$-D-mannuronic acid (M) and $\alpha$-L-guluronic acid (G) residues (Figure 3) [47,48], of widely varying composition and sequence according to: (i) algae, (ii) where they are developed and, (iii) the organs used for extraction.
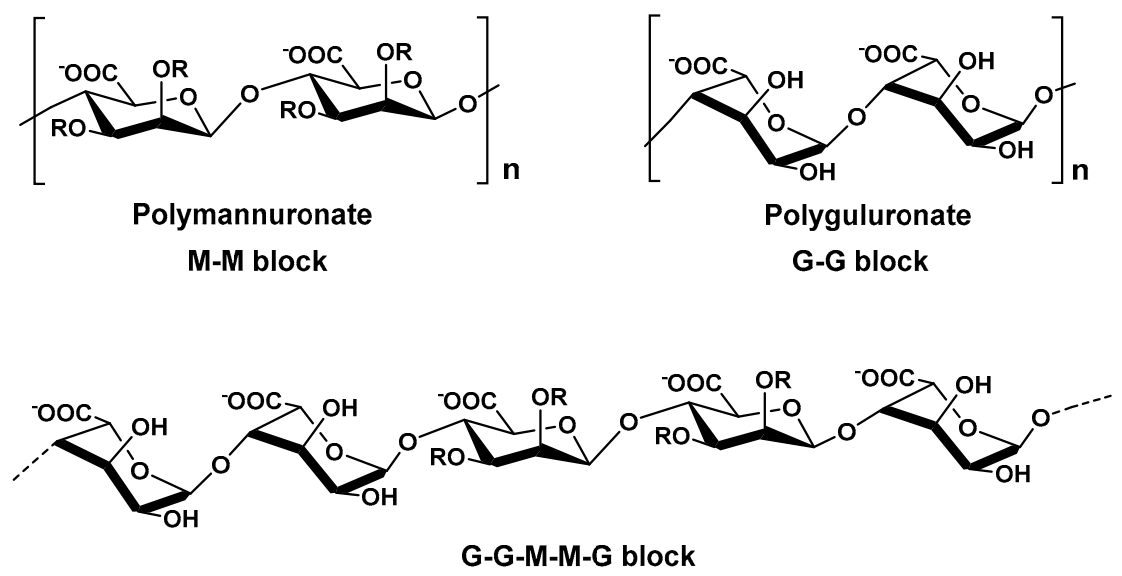

Figure 3. Mains structure of alginates. From algae with $\mathrm{R}=\mathrm{H}$ and from bacteria with $\mathrm{R}=\mathrm{H}$ or $\mathrm{COCH}_{3}$ (acetyl group).

However, it is still organized as homo- (MM blocks and GG blocks) and/or heteropolymeric blocks (MG blocks) [49]. Distribution, quantity and length of the MM, MG and GG blocks determine the rheological properties of alginates. Thus, high levels of $G$ blocks stiffen the alginate chains [49] and lead to more viscous solutions. It is in the presence of cations and especially $\mathrm{Ca}^{2+}$ ions that alginate forms gel (called egg box model) whose resistance is strongly influenced by the content and the length of the $G$ blocks $[48,49]$. Compared with other gelling polysaccharides, the most striking features of alginate's physical properties are the selective binding of multivalent cations, being the basis for gel formation and the fact that the sol/gel transition of alginates is not particularly influenced by temperature. Commercial alginates are produced mainly from Macrocystis pyrifera, Ascophyllum nodosum, Laminaria species, Eclonia maxima, Lessonia nigrescens, Durvillea Antarctica and Sargassum species [50]. Many processes are used to extract alginate [51-54]. In a general way, algae powder was first demineralized using acid solution such as $\mathrm{HCl}(0.1 \%-0.5 \%)$ and secondly treated with alkaline solution using $\mathrm{NaHCO}_{3}$ or $\mathrm{NaOH}(0.5$ to $2 \%$; $\mathrm{pH} 10-11)$ at $60-70{ }^{\circ} \mathrm{C}$ which easily allows the release of alginates in sodium salt form $[51,53]$. To increase yield, the alkali treatment is repeated 2-3 times. After filtration to eliminate insoluble residue, $\mathrm{CaCl}_{2}$ solution $(5 \%-15 \%(\mathrm{w} / \mathrm{v}))$ is added to the filtrate to precipitate alginate in calcium salt. Then, calcium alginate could be bleached using aqueous oxygen peroxide or sodium hypochlorite $(1 \%-10 \%(\mathrm{v} / \mathrm{v}))$ treatment followed by mixing with $\mathrm{HCl}$ solution $(1 \%-5 \%(\mathrm{v} / \mathrm{v}))$ to obtain alginic acid which is purify by repeated water washing to completely remove 
calcium salt $[48,49,51,52]$. Finally, the highly purified alginic acid form is usually: (i) converted to sodium alginate using carbonate or $\mathrm{NaOH}$ solution treatment, (ii) precipitated using alcohol (ethanol, isopropanol ... ), (iii) dried and (iv) ground in fine powder.

\subsubsection{Alginate from Azotobacter Vinelandii and Pseudomonas spp.}

Alginates are also synthesized as acetylated exopolysaccharides by certain bacterial species such as Pseudomonas aeruginosa and Azotobacter vinelandii [54,55]. During its vegetative growth Azotobacter vinelandii synthesizes alginate and intracellular polyesters (polyhydroxybutyrate) [56,57]. This alginate production is part of the enkystement process, as a mechanism for promoting resistance to desiccation under unfavourable environmental conditions in order to maintain hydration of the cell $[58,59]$ constituting a structural element of the cell [60]. In addition to this structural role that alginate plays in Azotobacter vinelandii and due to its guluronic acid content, it can also act as an oxygen diffusion barrier, limiting its transfer to the enzymatic complex of nitrogenase [61], which is very sensitive to oxygen [62]. In Pseudomonas aeruginosa, alginate is the causative agent of cystic fibrosis, and is associated with pathogenic power [59,63,64]. Alginate biosynthesis in Pseudomonas spp. is induced under desiccation conditions and is probably a key component of stable biofilms in various environments [58,59]. The main difference at the molecular level between algal and bacterial alginates is the presence of $\mathrm{O}$-acetyl groups at $\mathrm{C} 2$ and/or $\mathrm{C} 3$ of mannuronic acid unit in the bacterial alginates (Figure 3) [65].

\section{3D Bioprinting Technology Concept}

Parallel to the many advances made in science and technology, 3D printing has been applied to many multidisciplinary fields due to its unique physical, chemical and biological properties as well as multifunctional material-based construction. In addition, 3D printing has extended applicability toward the fabrication of three-dimensional constructs containing living cells. This technology is expected to solve the problem of the conventional tissue engineering approach and the arduous task of controlling the position of individual cells. In the conventional tissue engineering approach, cell-laden constructs are prepared by pouring cell-suspending solution to porous scaffolds. In contrast, in 3D bioprinting, cell-laden constructs are prepared by localizing cell-suspending bioink using printers as intended. The existing bioprinting systems can be roughly classified into four types (Figure 4) [12,66-68]: inkjet bioprinting (a), stereolithography bioprinting (b), micro-extrusion bioprinting (c), and laser-assisted bioprinting $(\mathrm{d})$.
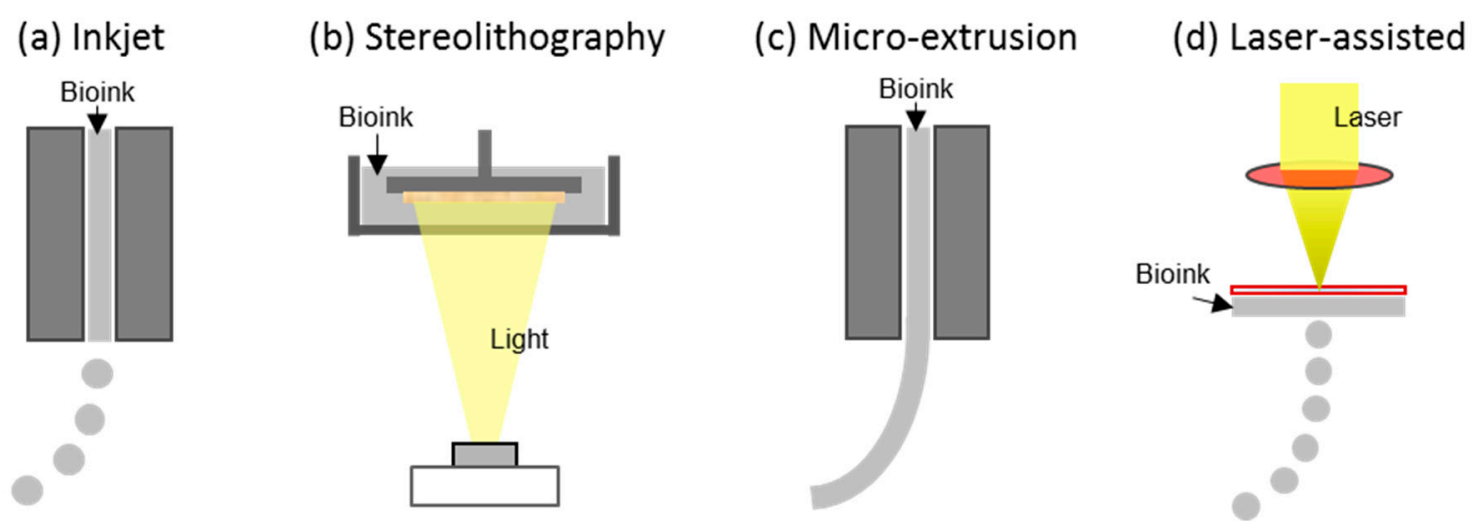

Figure 4. Schematic diagram of four common bioprinting systems.

Inkjet bioprinting system deposits droplets of bioink-containing cells on a substrate through an ejection from a small needle. Gelation of the deposited bioink should occur in-situ at the deposited position. The diameter of the droplets is within a range of several dozens to several hundred micrometers. An attractive point of inkjet bioprinting is a micrometer scale resolution $(10-50 \mu \mathrm{m})$. 
In contrast, a well-known limitation is the necessity of rapidly gellable bioinks with low viscosity $(<10 \mathrm{mPa} \cdot \mathrm{s})$ [66]. It is ideal for bioprinting systems, to enable hydrogelation processes that are cytocompatible. Stereolithography bioprinting requires bioinks curable through photo-irradiation using a rastered laser beam or a dynamically projected light source. Cell-laden constructs are fabricated on the surface of a substrate submerged in the bioink. When it comes to the quality, resolution, and accuracy of manufactured parts, stereolithography bioprinting is the most promising system. The difficulty of this approach is that the same layer cannot be fabricated by multiple bioinks. Micro-extrusion bioprinting is the most intensively investigated. 3D constructs are obtained by continuous extrusion of bioink filament fed through a needle.

The bioinks with the viscosity of $30-6 \times 10^{7} \mathrm{mPa} \cdot \mathrm{s}$ are applicable to this system [66]. In addition, in comparison with other bioprinting systems, micro-extrusion bioprinting enables one to prepare cell-laden constructs with higher cell density [12]. The existence of various applicable biomaterials and inexpensive printers are also attractive points of this system. Laser-assisted bioprinting is one of the most cutting-edge systems, which allows the printing of bioink inclusive of cells with a cell-level resolution. In this system, a pulsed laser beam is focused and scanned over a donor substrate that is coated with an absorbing layer and a layer of bioink. The resolution is in the range of 10-100 $\mu \mathrm{m}$. A few of the drawbacks of this printer is that it has a more complicated structure, it is relatively expensive, and irradiation of a laser beam can lead to cell damage [69].

\section{Biomaterial Application of Alginate in 3D Bioprinting and Perspectives Using Other Polyuronic Acid Polysaccharides}

Alginate, as a biomaterial for tissue engineering applications, has a number of attractive features such as biocompatibility, low toxicity, relatively low cost, and mild and rapid hydrogelation by the addition of divalent cations such as $\mathrm{Ca}^{2+}[70]$. The mild and rapid hydrogelation is useful as a component of bioink for stabilizing it at the designated position. In a pioneer work by Nakamura et al. for inkjet bioprinting, 3D cell-laden constructs were obtained by dropping sodium alginate solution containing cells into $\mathrm{CaCl}_{2}$ solution from an inkjet nozzle [71-73]. It is reported that successful fabrication of a cell-laden gel tube is around $400 \mu \mathrm{m}$ in diameter (Figure 5a). There is a commercially available bioink named Cellink (Cellink, Gothenburg, Sweden) which is composed of alginate, a cellulose nanofiber-containing polymer with enhanced shear-thinning properties. Due to the shear-thinning property, printed 3D constructs can retain the shape during printing. Post-printing, the constructs are gelated by reacting with an aqueous solution of $\mathrm{Ca}^{2+}$.

A noticeable drawback of sodium alginate for tissue engineering applications is the low cell attachment and characteristic spreading of the resultant hydrogels crosslinked by divalent cations. To address this problem, Jia et al. used an alginate conjugated with cell-adhesive RGD peptide for bioprinting [74]. Another approach in utilizing the hydrogelation feature is a combination with other materials having different properties with alginate such as hydroxyapatite [75] and gelatin [76]. Wüst et al. used a bioink containing gelatin, alginate, hydroxyapatite, and cells to print a novel cell-laden composite for bone printing using micro-extrusion bioprinting [76]. In the system, the bioink was first extruded onto a cooling plate for inducing thermal hydrogelation attributed to gelatin. Then, the resultant constructs were immersed in a solution containing $\mathrm{Ca}^{2+}$ for inducing cross-linking of alginate to improve a long-term structural integrity of the constructs including cells.

Alginate has also been used as a component of bioink after being introduced to phenolic hydroxyl moieties that proved to be cross-linkable under mild conditions. In these cases, the biocompatibility and low toxicity would be considered useful. Sun et al. fabricated 3D constructs through micro-extrusion bioprinting using bioink containing photo-cross-linkable and cell-adhesive alginate derivative obtained by introducing both methacrylate and RGD moieties onto the alginate backbone [77]. In the system, hydrogels were obtained through ultraviolet light-irradiation in the presence of a photo initiator. Sakai et al. reported stereography bioprinting using alginate derivatives obtained by introducing phenolic hydroxyl moieties through visible light irradiation in the presence of ruthenium II tris(bipyridyl) 
chloride and sodium persulfate (Figure 5b) [78]. Fibroblast cells enclosed in the hydrogel constructs showed more than $90 \%$ viability for seven days [78]. The same alginate derivative possessing phenolic hydroxyl moieties were also used as bioinks of inkjet bioprinting (Figure 5c) [79] and micro-extrusion bioprinting [80]. In these studies, the bioinks were gelated through horseradish peroxidase-catalyzed reaction. The enzyme-mediated hydrogelation was reported as rapid enough to fabricate 3D constructs with the shapes as designed $[79,80]$.

Hyaluronic acid (HA), one of the most important components of extracellular matrices, is a polysaccharide that has been intensively investigated as a component of bioink due to its excellent biocompatibility and biological properties [81,82]. Native HA is not gellable under physiological conditions, therefore introduction of cross-linkable moieties is necessary for the use as bioinks to fabricate the 3D constructs containing HA in stable. As the similar manner for alginate described above, HA derivatives possessing introduced methacrylate moieties [83] and phenolic hydroxyl moieties [79,84] were used in micro-extrusion bioprinting (Figure 5d) [83,84] and inkjet bioprinting [79]. Considering the various bioactive properties of each polysaccharide, these polysaccharides will be used as components of bioinks through the introduction of crosslinkable moieties catalyzed by enzymatic means.

(a)

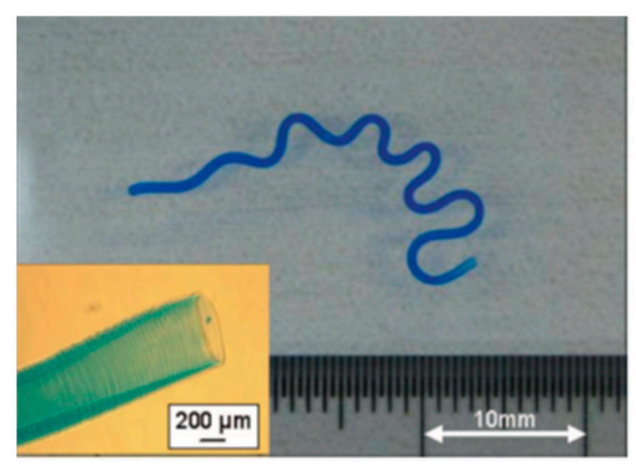

(c)

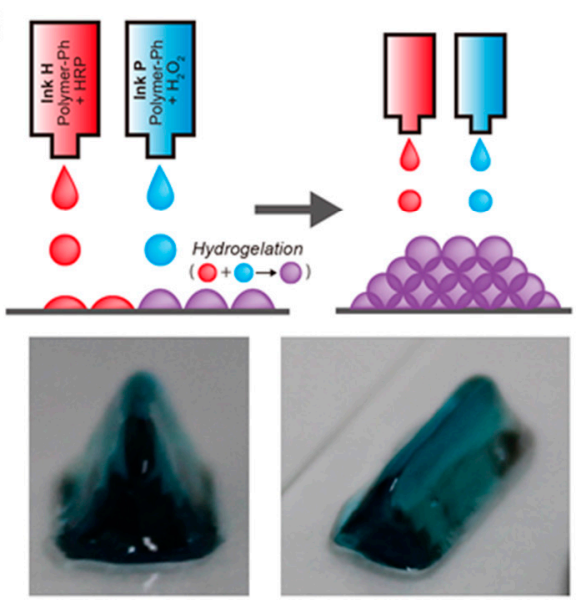

(b)
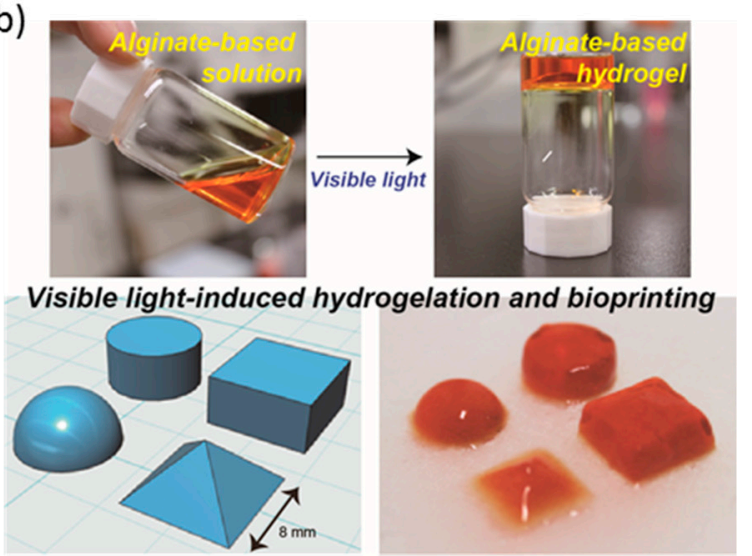

(d)

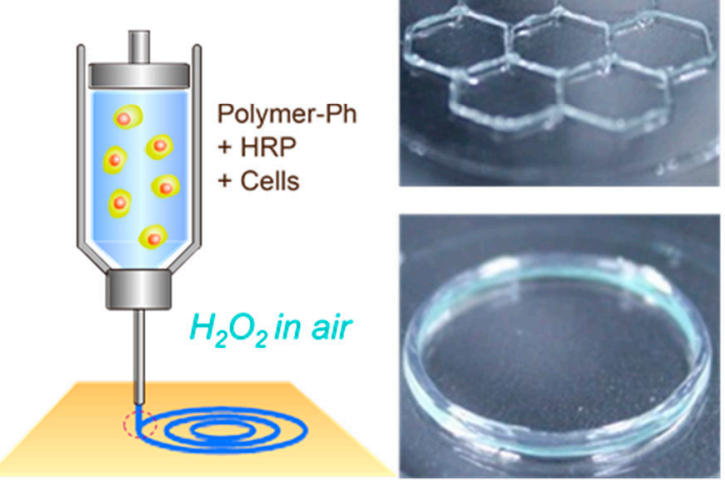

Figure 5. (a) Ca-alginate tube prepared through inkjet bioprinting, and hydrogel constructs obtained from $(\mathbf{b}, \mathbf{c})$ alginate derivative and (d) hyaluronic acid (HA) derivative possessing phenolic hydroxyl moieties through (b) stereolithograpy bioprinting, (c) inkjet bioprinting, and micro-extrusion bioprinting [80]. (a): adapted from Ref [73]. Copyright American Society of Mechanical Engineers; (b): adapted from Ref. [78]. Copyright American Chemical Society; (c): adapted from Ref. [79]. Copyright Wiley; (d): adapted from Ref. [80]. Copyright IOP Science. 


\section{Conclusions}

$3 \mathrm{D}$ printing has well earned its place in the fabrication of biomaterials. The emerging technology is only at the beginning of its industrial development. Indeed, the development of this technology is still very limited for the construction of 3D bio-based materials despite the abundance of the biopolymers. They are eco-friendly, renewable and sustainable polymers abundant in our very own biosphere. They also have functional groups in their structures which allow for chemical modification. However, the majority of these polymers have low printing performance and this issue must be addressed in order for this technology to be applied at industrial scales. Their formulation as chemically modified biopolymers and their use in combination with other components such as low-cost polyesters (polylactic acid for example) makes these compounds viable with improved printing properties. In parallel, the increase in performance of new-generation 3D printers may pave the way to the gradual utilization of natural biopolymers. The requirements of the regenerative medicine for biocompatible hydrogels and dried scaffolds with high levels of biocompatibility and biodegradability will be the greatest opportunity for polysaccharides to have an increased presence in the market of 3D printing processes. The natural evolution of living organisms gives rise to these macromolecules with numerous innate biological functions, mainly mimicking the architecture of tissues (cellulose from plants or chitin from fungi and animals) and providing a system to support life (hydrated extracellular matrix of cells). These biological functions are attributed to their unique mechanical properties (stiffness or swelling degree). In addition, a better understanding of 3D printed bio-based material interactions with the human body and its role in regenerative medicine will lead to a need for more specialized polysaccharides-optimized in design, processability and bioactivity. Although the field is in its early development, it has already created several human tissues approaching the scenario of the "Fifth Element" film. The success of future biocompatible artificial tissue obtained by 3D bioprinting will be also dependent on the capacity to reproduce the complexity of natural environment and tissues with gradients of matter having functionally adaptability. Polysaccharides are viable polymers to achieve this as they can generate a large variety of hydrogels; some of them having biological activities (hydrogels of glycosaminoglycans (GAG) or other sulfated polysaccharides, and polymers mimetic of GAG such as polyglucuronic acid). These high-value applications of polysaccharides in 3D printing would become the forefront in its path for specialized bio-ink. With a stronger presence in the market, lowered costs for polysaccharide processing would lead to greater access to even non-polysaccharide polymers such as lignins. This opens endless paths leading to sustainable and eco-friendly solutions that may be the alternative to what was once fictional.

Author Contributions: P.M. Wrote introduction and conclusion part; S.B., C.D. and G.P. wrote the Section 2; C.D. wrote the abstract; C.D. made the 1,2 and 3; S.B. made the Table 1; C.T., E.G., M.S.C., A.Y. and S.S. wrote Sections 3 and 4.; C.T., E.G., M.S.C., A.Y. and S.S. made Figures 4 and 5; C.D. prepared and revised the manuscript.

Funding: This research was funded by the PHC SAKURA 2019 program and Campus France, grant number 43019NM.

Conflicts of Interest: The authors declare no conflict of interest.

\section{References}

1. Kodama, H. Automatic method for fabricating a three-dimensional plastic model with photo-hardening polymer. Rev. Sci. Instrum. 1981, 52, 1770-1773. [CrossRef]

2. Crump, S.S. Apparatus and Method for Creating Three-Dimensional Objects. U.S. Patent No. 5,121,329, 9 June 1992.

3. Liu, J.; Sun, L.; Xu, W.; Wang, Q.; Yu, S.; Sun, J. Current advances and future perspectives of 3D printing natural-derived biopolymers. Carbohyd. Polym. 2019, 207, 297-316. [CrossRef] [PubMed]

4. Yanagawa, F.; Sugiura, S.; Kanamori, T. Hydrogel microfabrication technology toward three dimensional tissue engineering. Regen. Ther. 2016, 3, 45-57. [CrossRef]

5. Hong, N.; Yang, G.H.; Lee, J.; Kim, G. 3D bioprinting and its in vivo applications. J. Biomed. Mater. Res. B Appl. Biomater. 2018, 106, 444-459. [CrossRef] 
6. Sutherland, I.W. Bacterial exopolysaccharides. In Comprehensive Glycoscience: From Chemistry to System Biology; Boons, G.-J., Kamerling, J.P., Lee, Y.C., Suzuki, A., Taniguchi, N., Voragen, A.G.J., Eds.; Elsevier B.V.: Oxford, UK, 2007; Volume 2, pp. 521-557.

7. Laroche, C.; Michaud, P. New developments and prospective applications for $(1,3)$ glucans. Rec. Pat. Biotechnol. 2007, 1, 59-73. [CrossRef]

8. Delattre, C.; Pierre, G.; Laroche, C.; Michaud, P. Production, extraction and characterization of microalgal and cyanobacterial exopolysaccharides. Biotechnol. Adv. 2016, 34, 1159-1179. [CrossRef] [PubMed]

9. Pierre, G.; Delattre, C.; Laroche, C.; Michaud, P. Galactans and its applications. In Polysaccharides; Springer International Publishing: Cham, Switzerland, 2014. [CrossRef]

10. Giustina, G.D.; Gandin, A.; Brigo, L.; Panciera, T.; Giulitti, S.; Sgarbossa, P.; D'Alessandro, D.; Trombi, L.; Danti, S.; Brusatin, G. Polysaccharide hydrogels for multiscale 3D printing of pullulan scaffolds. Mater. Des. 2019, 165, 107566. [CrossRef]

11. Mohan, T.; Maver, T.; Štiglic, A.D.; Stana-Kleinschek, K.; Kargl, R. 3D bioprinting of polysaccharides and their derivatives: From characterization to application. In Fundamental Biomaterials: Polymers; Elsevier Ltd.: Amsterdam, the Netherlands, 2018. [CrossRef]

12. Murphy, S.V.; Atala, A. 3D bioprinting of tissues and organs. Nat. Biotechnol. 2014, 32, 773-785. [CrossRef]

13. Ab-Rahim, S.; Selvaratnam, L.; Raghavendran, H.R.B.; Kamarul, T. Chondrocyte-alginate constructs with or without TGF-1 produces superior extracellular matrix expression than monolayer cultures. Mol. Cell. Biochem. 2013, 376, 11-20. [CrossRef]

14. Elboutachfaiti, R.; Delattre, C.; Petit, E.; Michaud, P. Polyglucuronics acids: Structures, functions and degrading enzymes. Carbohydr. Polym. 2011, 84,1-13. [CrossRef]

15. Purcell, E.K.; Singh, A.; Kipke, D.R. Alginate composition effects on a neural stem cell-seeded scaffold. Tissue Eng. Part C Methods 2009, 15, 541-550. [CrossRef]

16. Luo, S.J.; Chen, R.Y.; Huang, L.; Liang, R.H.; Liu, C.-M.; Chen, J. Investigation on the influence of pectin structures on the pasting properties of rice starch by multiple regression. Food Hydrocoll. 2017, 63, 580-584. [CrossRef]

17. Pérez, S.; Rodríguez-Carvajal, M.A.; Doco, T. A complex plant cell wall polysaccharide: Rhamnogalacturonan II.A structure in quest of a function. Biochimie 2003, 85, 109-121. [CrossRef]

18. Taylor, K.A.; Buchanan-Smith, J.G. A colorimetric method for the quantitation of uronic acids and a specific assay for galacturonic acid. Anal. Biochem. 1992, 201, 190-196. [CrossRef]

19. Aspinall, G.O. Chemistry of cell wall polysaccharides. In The Biochemistry of Plants; Preiss, J., Ed.; Academic Press: New York, NY, USA, 1980; pp. 473-500.

20. Voragen, A.G.J.; Pilnik, W.; Thibault, J.F.; Axelos, M.A.V.; Renard, C.M.G.C. Pectins. In Food Polysaccharides and Their Applications; Stephen, A.M., Ed.; Marcel Dekker: New York, NY, USA, 1995; pp. 287-339.

21. Axelos, M.A.V.; Thibault, J.F. Influence of the substituents of the carboxyl groups and the rhamnose content on the solution properties and flexibility of pectins. Int. J. Biol. Macromol. 1991, 13, 77-82. [CrossRef]

22. Renard, C.M.G.C.; Jarvis, M.C. Acetylation and methylation of homogalacturonans. Part II. Effect on ion-binding properties and conformations. Carbohydr. Polym. 1999, 39, 209-216. [CrossRef]

23. Massiot, P.; Rouau, X.; Thibault, J.F. characterisation of the extractable pectins and hemicelluloses of the cell wall of carrot. Carbohydr. Res. 1988, 172, 229-242. [CrossRef]

24. Guillon, F.; Thibault, J.F. Further characterization of acid- and alkali-soluble pectins from sugar beet pulp. LMT-Food Sci. Technol. 1988, 21, 198-205.

25. Saulnier, L.; Thibault, J.F. Extraction and characterization of pectic substances from pulp of grape berries. Carbohydr. Polym. 1987, 7, 329-343. [CrossRef]

26. Renard, C.M.G.C.; Weightman, R.M.; Thibault, J.F. Structure of the xylose-rich pectins from pea hulls. Int. J. Biol. Macromol. 1997, 21, 155-162. [CrossRef]

27. Renard, C.M.G.C.; Champenois, Y.; Thibault, J.F. Characterization of the extractable pectins and hemicelluloses of the cell wall of glasswort, Salicornia ramosissima. Carbohydr. Polym. 1993, 22, 239-245. [CrossRef]

28. Blumenkrantz, N.; Asboe-Hansen, G. New method for quantitative determination of uronic acids. Anal. Biochem. 1973, 54, 484-489. [CrossRef]

29. Scott, R.W. Colorimetric determination of hexuronic acids in plant materials. Anal. Chem. 1979, 51, $936-941$. [CrossRef] 
30. Thibault, J.F. Automatisation du dosage des substances pectiques par la méthode au métahydroxydiphényle. LMT-Food Sci. Technol. 1979, 12, 247-251.

31. Heyraud, A.; Courtois, J.; Dantas, L.; Colin-Morel, P.; Courtois, B. Structural characterization and rheological properties of an extracellular glucuronan produced by a Rhizobium meliloti M5N1 mutant strain. Carbohydr. Res. 1993, 240, 71-78. [CrossRef]

32. Dantas, L.; Courtois, J.; Courtois, B.; Séguin, J.P.; Gey, C.; Heyraud, A. NMR spectroscopic investigation of oligoglucuronates prepared by enzymic hydrolysis of a (1,4) beta-D-glucuronan. Carbohydr. Res. 1994, 265, 303-310. [CrossRef]

33. Courtois-Sambourg, J.; Courtois, B.; Heyraud, A.; Colin-Morel, P.; Rinaudo-Duhem, M. Polymer Compounds of the Glycuronic Acid, Method of Preparation and Utilization Particularly as Gelifying, Thickening, Hydrating, Stabilizing, Chelating or Floculating Means. Patent WO1,993,018,174, 16 September 1993.

34. Tavernier, M.L.; Petit, E.; Delattre, C.; Courtois, B.; Courtois, J.; Strancar, A. Production of oligoglucuronans using a monolithic enzymatic microreactor. Carbohydr. Res. 2008, 343, 2687-2691. [CrossRef] [PubMed]

35. Park, J.K.; Park, Y.H.; Jung, J.Y. Production of bacterial cellulose by Gluconacetobacter hansenii PJK isolated from rotten apple. Biotechnol. Biop. Eng. 2003, 8, 83-88. [CrossRef]

36. Jung, J.Y.; Park, J.K.; Chang, H.N. Bacterial cellulose production by Gluconacetobacter hansenii in an agitated culture without living non cellulose producing cells. Enzym. Microb. Technol. 2005, 37, 347-354. [CrossRef]

37. Park, J.K.; Hyun, S.H.; Jung, J.Y. Conversion of G. hansenii PJK into noncellulose-producing mutants. Biotechnol. Bioprocess Eng. 2004, 9, 383-388. [CrossRef]

38. Shah, N.; Ha, J.H.; Park, J.K. Effect of reactor surface on production of bacterial cellulose and water-soluble oligosaccharides by Gluconacetobacter hansenii PJK. Biotechnol. Bioprocess Eng. 2010, 15, 110-118. [CrossRef]

39. Khan, T.; Hyun, S.H.; Park, J.K. Physical properties of a single sugar-linked glucuronic acid-based oligosaccharides produced by a Gluconacetobacter hansenii strain. Process Biochem. 2007, 42, 252-257. [CrossRef]

40. Park, J.K.; Khan, T.; Jung, J.Y. Structural studies of the glucuronic acid oligomers produced by Gluconacetobacter hansenii strain. Carbohydr. Polym. 2006, 63, 482-486. [CrossRef]

41. Khan, T.; Park, J.K. The structure and physical properties of glucuronic acid oligomers produced by a Gluconacetobacter hansenii strain using the waste from beer fermentation broth. Carbohydr. Polym. 2008, 73, 438-445. [CrossRef]

42. Bartnicki-Garcia, S.; Nickerson, W.J. Isolation, composition, and structure of cell walls of filaments and yeast-like forms of Mucor rouxii. Biochim. Biophys. Acta 1962, 58, 102-119. [CrossRef]

43. Bartnicki-Garcia, S.; Reyes, E. Polyuronides in the cell wall of Mucor rouxii. Biochim. Biophys. Acta 1968, 170, 54-62. [CrossRef]

44. Dow, J.M.; Darnall, D.W.; Villa, V.D. Two distinct classes of polyuronide from the cell walls of a dimorphic fungus, Mucor rouxii. J. Bacteriol. 1983, 155, 1088-1093.

45. Ray, B. Polysaccharides from Enteromorpha compressa: Isolation, purification and structural features. Carbohydr. Polym. 2006, 66, 408-416. [CrossRef]

46. Ray, B.; Lahaye, M. Cell-wall polysaccharides from the marine green alga Ulva "rigida" (Ulvales, Chlorophyta). Chemical structure of ulvan. Carbohydr Res. 1995, 274, 313-318. [CrossRef]

47. Hentati, F.; Delattre, C.; Ursu, A.V.; Desbrières, J.; Le Cerf, D.; Gardarin, C.; Abdelkafi, S.; Michaudn, P.; Pierre, G. Structural characterization and antioxidant activity of water-soluble polysaccharides from the Tunisian brown seaweed Cystoseira compressa. Carbohydr. Polym. 2018, 198, 589-600. [CrossRef]

48. Gacesa, P. Alginates. Carbohydr. Polym. 1988, 8, 161-182. [CrossRef]

49. Draget, K.I.; Smidsrød, O.; Skjak-Braek, G. Alginates from Algae. In Biopolymers: Polysaccharides from Eukaryotes; De Baets, S., Vandamme, E.J., Steinbüchel, A., Eds.; Wileg-VCH: Weinheim, Germany, 2002; pp. 215-244.

50. Smidsrod, O; Draget, K.I. Alginates: Chemistry and physical properties. Carbohydr. Eur. 1996, 14, 6-13.

51. Rinaudo, M. Seaweed polysaccharides. In Comprehensive Glycoscience: From Chemistry to Systems Biology; Kamerling, J.P., Ed.; Elsevier Science: Amsterdam, the Netherland, 2007; Volume 2, pp. 691-735.

52. Cosenza, V.A.; Navarro, D.A.; Ponce, N.M.A. Seaweed Polysaccharides: Structure and Applications. In Industrial Applications of Renewable Biomass Products; Goyanes, S., D’Accorso, N., Eds.; Springer: Cham, Switzerland, 2017. 
53. Laurienzo, P. Marine polysaccharides in pharmaceutical applications: An overview. Mar. Drugs 2010,8, 2435-2465. [CrossRef] [PubMed]

54. Ertesvåg, H.; Valla, S. Biosynthesis and applications of alginates. Polym. Degr. Stab. 1998, 59, 85-91. [CrossRef]

55. Lim, S.J.; Aida, W.M.W. Chapter 3-Extraction of Sulfated Polysaccharides (Fucoidan) from Brown Seaweed. In Seaweed Polysaccharides: Isolation, Biological and Biomedical Applications; Elsevier: Cham, Switzerland, 2017; pp. 27-46.

56. Galindo, E.; Peña, C.; Núñez, C.; Segura, D.; Espin, G. Molecular and bioengineering strategies to improve alginate and polyhydroxyalkanoate production by Azotobacter vinelandii. Microb. Cell Fact. 2007, 6, 1-16. [CrossRef]

57. Rehm, B.H. Bacterial polymers: Biosynthesis, modifications and applications. Nat. Rev. Microbiol. 2010, 8 , 578-592. [CrossRef] [PubMed]

58. Gacesa, P. Bacterial alginate biosynthesis-recent progress and future prospects. J. Microbiol. 1998, 144, 1133-1143. [CrossRef]

59. Hay, I.D.; Wang, Y.; Moradali, M.F.; Rehman, Z.U.; Rehm, B.H. Genetics and regulation of bacterial alginate production. Appl. Environ. Microbiol. 2014, 16, 2997-3011. [CrossRef]

60. Remminghorst, U.; Rehm, B.H.A. In vitro alginate polymerization and the functional role of Alg8 in alginate production by Pseudomonas aeruginosa. Appl. Environ. Mirobiol. 2006, 72, 298-305. [CrossRef]

61. Sabra, W.; Zeng, A.P.; Lünsdorf, H.; Deckwer, W.D. Effect of oxygen on formation and structure of Azotobacter vinelandii and its role in protecting nitrogenase. Appl. Environ. Microbiol. 2000, 66, 4037-4044. [CrossRef]

62. Oelze, J. Respiratory protection of nitrogenase in Azotobacter species: Is a widely held hypothesis unequivocally supported by experimental evidence. FEMS Microbiol. Rev. 2000, 24, 321-333. [CrossRef] [PubMed]

63. Ramphal, R.; Pier, G.B. Role of Pseudomonas aeruginosa mucoid exopolysaccharide in adherence to tracheal cell. Infect. Inmmun. 1985, 47, 1-4.

64. Franklin, M.J.; Nivens, D.E.; Weadge, J.T.; Lynne Howell, P. Biosynthesis of the Pseudomonas aeruginosa extracellular polysaccharides, alginate, Pel and Psl. Front. Microbiol. 2011, 2, 1-15. [CrossRef] [PubMed]

65. Skajak-Braek, G.; Larsen, B.; Grasdalen, H. Monomer sequence and acetylation pattern in some bacterial alginates. Carbohydr. Res. 1986, 154, 239-250. [CrossRef]

66. Holzl, K.; Lin, S.M.; Tytgat, L.; Van Vlierberghe, S.; Gu, L.X.; Ovsianikov, A. Bioink properties before, during and after 3D bioprinting. Biofabrication 2016, 8, 032002. [CrossRef] [PubMed]

67. Gudapati, H.; Dey, M.; Ozbolat, I. A comprehensive review on droplet-based bioprinting: Past, present and future. Biomaterials 2016, 102, 20-42. [CrossRef] [PubMed]

68. Pedde, R.D.; Mirani, B.; Navaei, A.; Styan, T.; Wong, S.; Mehrali, M.; Thakur, A.; Mohtaram, N.K.; Bayati, A.; Dolatshahi-Pirouz, A.; et al. Emerging biofabrication strategies for engineering complex tissue constructs. Adv. Mater. 2017, 29, 1606061. [CrossRef] [PubMed]

69. Hopp, B.; Smausz, T.; Szabo, G.; Kolozsvari, L.; Kafetzopoulos, D.; Fotakis, C.; Ngrdi, A. Femtosecond laser printing of living cells using absorbing film-assisted laser-induced forward transfer. Opt. Eng. 2012, 51, 014302. [CrossRef]

70. Lee, K.Y.; Mooney, D.J. Alginate: Properties and biomedical applications. Prog. Polym. Sci. 2012, 37, $106-126$. [CrossRef] [PubMed]

71. Nakamura, M.; Kobayashi, A.; Takagi, F.; Watanabe, A.; Hiruma, Y.; Ohuchi, K.; Iwasaki, Y.; Horie, M.; Morita, I.; Takatani, S. Biocompatible inkjet printing technique for designed seeding of individual living cells. Tissue Eng. 2005, 11, 1658-1666. [CrossRef]

72. Nakamura, M.; Nishiyama, Y.; Henmi, C.; Iwanaga, S.; Nakagawa, H.; Yamaguchi, K.; Akita, K.; Mochizuki, S.; Takiura, K. Ink jet three-dimensional digital fabrication for biological tissue manufacturing: Analysis of alginate microgel beads produced by ink jet droplets for three dimensional tissue fabrication. J. Imaging Sci. Technol. 2008, 52, 060201-060206. [CrossRef]

73. Nishiyama, Y.; Nakamura, M.; Henmi, C.; Yamaguchi, K.; Mochizuki, S.; Nakagawa, H.; Takiura, K. Development of a three-dimensional bioprinter: Construction of cell supporting structures using hydrogel and state-of-the-art inkjet technology. J. Biomech. Eng. 2009, 131, 035001. [CrossRef] [PubMed] 
74. Jia, J.; Richards, D.J.; Pollard, S.; Tan, Y.; Rodriguez, J.; Visconti, R.P.; Trusk, T.C.; Yost, M.J.; Yao, H.; Markwald, R.R.; et al. Engineering alginate as bioink for bioprinting. Acta Biomater. 2014, 10, 4323-4331. [CrossRef] [PubMed]

75. Wang, Q.; Xia, Q.; Wu, Y.; Zhang, X.; Wen, F.; Chen, X.; Zhang, S.; Heng, B.C.; He, Y.; Ouyang, H.W. 3D-printed Atsttrin-incorporated alginate/hydroxyapatite scaffold promotes bone defect regeneration with TNF/TNFR signaling involvement. Adv. Healthc. Mater. 2015, 4, 1701-1708. [CrossRef] [PubMed]

76. Wust, S.; Godla, M.E.; Muller, R.; Hofmann, S. Tunable hydrogel composite with two-step processing in combination with innovative hardware upgrade for cell-based three-dimensional bioprinting. Acta Biomater. 2014, 10, 630-640. [CrossRef] [PubMed]

77. Sun, J.; Wei, D.; Yang, K.; Yang, Y.; Liu, X.L.; Fan, H.S.; Zhang, X.D. The development of cell-initiated degradable hydrogel based on methacrylated alginate applicable to multiple microfabrication technologies. J. Mater. Chem. B. 2017, 5, 8060-8069. [CrossRef]

78. Sakai, S.; Kamei, H.; Mori, T.; Hotta, T.; Ohi, H.; Nakahata, M.; Taya, M. Visible light-induced hydrogelation of an alginate derivative and application to stereolithographic bioprinting using a visible light projector and Acid Red. Biomacromolecules 2018, 19, 672-679. [CrossRef]

79. Sakai, S.; Ueda, K.; Gantumur, E.; Taya, M.; Nakamura, M. Drop-On-Drop multimaterial 3D bioprinting realized by peroxidase-mediated cross-linking. Macromol. Rapid Commun. 2018, 39, 1700534. [CrossRef]

80. Sakai, S.; Mochizuki, K.; Qu, Y.; Mail, M.; Nakahata, M.; Taya, M. Peroxidase-catalyzed microextrusion bioprinting of cell-laden hydrogel constructs in vaporized ppm-level hydrogen peroxide. Biofabrication 2018, 10, 045007. [CrossRef]

81. Casale, M.; Moffa, A.; Vella, P.; Sabatino, L.; Capuano, F.; Salvinelli, B.; Lopez, M.A.; Carinci, F.; Salvinelli, F. Hyaluronic acid: Perspectives in dentistry. A systematic review. Int. J. Immunopathol. Pharmacol. 2016, 29, 572-582. [CrossRef]

82. Pre, E.D.; Conti, G.; Sbarbati, A. Hyaluronic acid (HA) scaffolds and multipotent stromal cells (MSCs) in regenerative medicine. Stem Cell Rev. Rep. 2016, 12, 664-681. [CrossRef] [PubMed]

83. Poldervaart, M.T.; Goversen, B.; de Ruijter, M.; Abbadessa, A.; Melchels, F.P.W.; Oner, F.C.; Dhert, W.J.A.; Vermonden, T.; Alblas, J. 3D bioprinting of methacrylated hyaluronic acid (MeHA) hydrogel with intrinsic osteogenicity. PLoS ONE 2017, 12, e0177628. [CrossRef] [PubMed]

84. Sakai, S.; Ohi, H.; Hotta, T.; Kamei, H.; Taya, M. Differentiation potential of human adipose stem cells bioprinted with hyaluronic acid/gelatin-based bioink through microextrusion and visible light-initiated crosslinking. Biopolymers 2018, 109, e23080. [CrossRef] [PubMed] 